\title{
Validity of contour-clamped homogeneous electric field electrophoresis as a typing system for Candida albicans
}

\author{
Die Validität der CHEF-Pulsfeldelektrophorese als Typisierungs- \\ system für Candida albicans
}

J. A. Sangeorzan ${ }^{1}$, M.J. Zervos ${ }^{2}$, Susan Donabedian ${ }^{2}$ and Carol A. Kauffman ${ }^{1}$

Key words. Candida albicans, typing, kariotyping, CHEF electrophoresis.

Schlthsselwörter. Candida albicans, Typisierung, Kariotypisierung, CHEF-Pulsfeldelektrophorese.

Summary. Instigated by an increase in serious human Candida infections and aided by advances in technology, there has been renewed interest in the study of the epidemiology of fungal infections. Among the newer techniques available, contourclamped homogeneous electric field (CHEF) electrophoresis has shown great promise as a tool for typing strains of Candida albicans. However, few studies have addressed the reproducibility of the preparatory and electrophoretic methods. Through a series of analyses on clinical isolates of C. albicans, we were able to demonstrate that (a) sample preparation induced no appreciable artifacts in CHEF banding patterns; (b) the electrophoretic patterns were reproducible over time; (c) changes in colony morphology were not associated with changes in the electrophoretic pattern, and (d) the method was more sensitive than restriction enzyme analysis (REA) for demonstrating strain differences. CHEF electrophoresis is a sensitive and reproducible tool for the study of Candida epidemiology. Further use and study of this methodology is warranted.

Zusammenfassung. Die Zunahme schwerer Candida-Infektionen sowie technologische Fort-

\footnotetext{
${ }^{1}$ Division of Infectious Diseases, Department of Internal Medicine, University of Michigan Medical School, Department of Veterans Affairs Medical Center, Ann Arbor, Michigan, and ${ }^{2}$ Division of Infectious Diseases, Department of Internal Medicine, William Beaumont Medical Center, Wayne State University Medical School, Royal Oak,
} Michigan, USA.

Correspondence: Dr Carol A. Kauffman, Veterans Affairs Medical Center, 2215 Fuller Road, Ann Arbor, Michigan 48105, USA. schritte haben das Interesse an der Epidemiologie von Pilzinfektionen neu belebt. Unter den neueren Techniken hat sich die CHEF-Pulsfeldelektrophorese als vielversprechendes Werkzeug zur Stammtypisierung von Candida albicans herausgestellt. Bisher sind jedoch nur wenige Studien zur Reproduzierbarkeit der präparativen und elektrophoretischen Methoden gemacht worden. Mittels einer Serie von Analysen klinischer $C$. albicans-Isolate waren wir in der Lage zu zeigen, daß (a) die Probenpräparation keine wesentlichen Artefakte im CHEF-Bandenmuster hervorruft, daß (b) die elektrophoretischen Muster wiederholt reproduzierbar waren, daß (c) Veränderungen in der Koloniemorphologie nicht mit Veränderungen in den elektrophoretischen Mustern verbunden waren und daß (d) die Methode empfindlicher war als die Restriktionsenzym-Analyse (REA) für das Aufdecken von Stammunterschieden. Die CHEFPulsfeldelektrophorese ist ein empfindliches und reproduzierbares Verfahren für Studien zur Candida-Epidemiologie. Der weitere Einsatz und weitere Untersuchungen mit dieser Methode bieten sich an.

\section{Introduction}

Our knowledge of the epidemiology of Candida albicans has been limited by the lack of a sensitive, specific, reproducible, and readily available typing system. Attempts at typing have used differences in colony morphology, biochemical activity, toxin secretion, serology, and protein production [1-7], but no one method has been entirely satisfactory.

Recently, molecular techniques used to study 
the epidemiology of bacteria have been applied to C. albicans. Agarose gel electrophoresis of restriction endonuclease digested DNA has been used successfully to differentiate strains of $C$. albicans, and appears to be more sensitive than older methods [7-11]. Even though sensitive and reproducible, this method is time intensive and requires the use of toxic and expensive reagents.

Contour-clamped homogeneous electric field (CHEF) electrophoresis, a refinement of pulsedfield electrophoresis, uses variations in electric field vectors to separate large molecular weight DNA on standard agarose gels [12]. It can be applied to intact chromosomal DNA, allowing clear separation of multiple bands and obviating the need for DNA extraction and restriction digestion $[7,9,11,13,14]$. Some studies indicate that CHEF is more sensitive than restriction enzyme analysis for typing Candida species [15].

Any technique used for studying the epidemiology of $C$. albicans must prove to be reproducible over time. It has been suggested that Candida species undergo high frequency chromosomal rearrangement, which may be responsible for changes in colony morphology [16]. Such changes could affect the reproducibility of CHEF banding patterns. In addition, the reproducibility of sample preparation, electrophoretic parameters, and analysis of banding patterns have not been adequately addressed in the literature.

We set out to answer the following questions: (a) Does the preparation of Candida DNA for CHEF electrophoresis induce artifacts in banding patterns? (b) Are the electrophoresis procedures and data analyses highly reproducible? (c) Are environmentally induced changes in colony morphology reflected in CHEF banding patterns? and (d) Is CHEF more sensitive than restriction enzyme analysis for delineating strains of $C$. albicans?

\section{Materials and methods}

\section{Yeast isolates}

C. albicans isolates used for these studies were randomly selected from different patients from whom a large number of clinical isolates were obtained as part of an epidemiologic study in an extended care facility. Yeasts were identified as C. albicans by germ tube formation in human serum after $2 \mathrm{~h}$ incubation at $37^{\circ} \mathrm{C}$, and verified by the Yeast API 20C method (Sherwood Medical, Plainview, NY, USA). Isolates were stored in brain heart infusion (BHI) broth (Difco, Detroit, USA) at $-70^{\circ} \mathrm{C}$ until studies were performed.

\section{Yeast DNA insert preparation}

Frozen stocks were thawed, streaked for isolation on Sabouraud glucose agar (Difco) plates and incubated for $48 \mathrm{~h}$ at $30^{\circ} \mathrm{C}$. A volume of $45 \mathrm{ml}$ of YEPD broth (Yeast Extract $1 \mathrm{~g} 100 \mathrm{ml}^{-1}$,

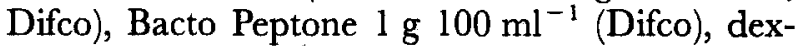
trose $2 \mathrm{~g} 100 \mathrm{ml}^{-1}$ ) in deionized, distilled water was inoculated with a single yeast colony, and incubated for $48 \mathrm{~h}$ at $37^{\circ} \mathrm{C}$ in a $5 \% \quad \mathrm{CO}_{2}$ atmosphere.

The DNA was prepared as described by Schwartz and Cantor [12], and modified by Vazquez et al. [17]. In brief, the suspended yeast cells were centrifuged and washed twice with $75 \mathrm{mM} \mathrm{NaCl}-25 \mathrm{mM}$ EDTA solution. The washed cells were embedded in a matrix of $10 \mathrm{mg} \mathrm{ml}^{-1}$ Type VII low melting point agarose (Sigma, St. Louis, USA), with 80 units zymolyase (ICN Biomedicals, Costa Mesa, Ca, USA) in $1.5 \times 10 \times 20 \mathrm{~mm}$ plug molds. Spheroplast formation was induced by incubating the agarose plugs overnight at $37{ }^{\circ} \mathrm{C}$ in $2.5 \mathrm{ml}$ of $7.5 \%$ mercaptoethanol-500 mM EDTA. After cooling and rinsing with $50 \mathrm{mM}$ EDTA, cells were lysed in $2.5 \mathrm{ml}$ of ESP $(0.5 \mathrm{M}$ EDTA, pH 9; $1 \%$ sarcosine, $5 \mathrm{mg} \mathrm{ml}^{-1}$ [Sigma]; and pronase, $20 \mu \mathrm{g} \mathrm{ml}^{-1}$ [Boehringer Mannheim, Germany]) solution overnight at $50{ }^{\circ} \mathrm{C}$. After rinsing in $50 \mathrm{mM}$ EDTA, the finished plugs were stored in 0.5 M EDTA, $\mathrm{pH} 9$, at $4{ }^{\circ} \mathrm{C}$ until analysed.

\section{CHEF electrophoresis}

Portions of the prepared agarose plugs containing whole yeast cell DNA were loaded onto a 15 lane horizontal electrophoresis gel prepared as $1 \%$ Ultrapure Agarose (BRL, Gaithersburg, MD, USA) in 0.5X TBE buffer (Sigma, St. Louis, USA). All gels contained chromosomal DNA from Saccharomyces cerevisiae (Yeast Ghromosomal DNA, BioRad, Richmond, CA, USA) to act as internal standards of known banding pattern and molecular weight. Chromosomal separation was achieved on a BioRad CHEF DR-II apparatus using the following parameters: $150 \mathrm{~V}, 120 \mathrm{~s}$ switch time for $20 \mathrm{~h}$; followed by $150 \mathrm{~V}, 300 \mathrm{~s}$ switch time for $20 \mathrm{~h}$; followed by $115 \mathrm{~V}, 300 \mathrm{~s}$ switch time for $24 \mathrm{~h}$. Running buffer was $0.5 \mathrm{X}$ TBE chilled to $12{ }^{\circ} \mathrm{C}$ and changed every $24 \mathrm{~h}$. Buffer temperature was maintained by a BioRad Mini-chiller. Gels were stained for $1 \mathrm{~h}$ in $1 \mu \mathrm{g} \mathrm{ml}^{-1}$ ethidium bromide, de-stained in distilled water, and photographed using UV trans-illumination. C. albicans strain differentiation was performed by direct comparison of the banding pattern of each isolate as 
visualized on $5 \times 7$ enlargements of the gel photographs.

\section{Restriction enzyme analysis}

For the isolation of DNA, yeast cells were grown on Sabouraud glucose agar plates for $48 \mathrm{~h}$ at $30^{\circ} \mathrm{C}$. A single yeast colony was inoculated into $200 \mathrm{ml}$ of YEPD broth and incubated for $48 \mathrm{~h}$ at $30^{\circ} \mathrm{C}$. The method used to prepare the DNA was a modification of the method described by Vazquez et al. $[15,17]$. Briefly, the harvested cells were suspended in $5.0 \mathrm{ml}$ of $0.2 \mathrm{M}$ TRIS-HCl $5 \%$ $\beta$-mercaptoethanol and incubated in a water bath at $37^{\circ} \mathrm{C}$ for $30 \mathrm{~min}$. After incubation, $10 \mathrm{ml}$ of $1 \mathrm{M}$ sorbitol- $0.004 \mathrm{M}$ potassium phosphate was added and the cells were pelleted. The cells were then resuspended in $2.5 \mathrm{ml}$ of sorbitol-potassium phosphate and 80 units $\mathrm{g}^{-1}$ cell weight of zymolyase $20 \mathrm{~T}$ (ICN Biomedical, Lisle, IL, USA) to promote spheroplast formation. The spheroplasts were then lysed using a solution of $0.2 \mathrm{M}$ sodium chloride, $0.1 \mathrm{M}$ EDTA, $5 \% \mathrm{SDS}, 50 \mathrm{mM}$ TRIS ( $\mathrm{pH} \mathrm{8.5),} \mathrm{and} 20 \mu \mathrm{g} \mathrm{ml}^{-1}$ of pronase (Sigma, St. Louis) and incubated at $56{ }^{\circ} \mathrm{C}$ for $30 \mathrm{~min}$ in a water bath. Nucleic acids were extracted with phenol-chloroform $(25: 24)$ saturated with $10 \mathrm{mM}$ TRIS, $1 \mathrm{mM}$ EDTA (pH 8.4) and then precipitated with 2 volumes of ethanol at $-70^{\circ} \mathrm{C}$. The nucleic acids were pelleted, dried and resuspended in $1 \mathrm{ml}$ of TE buffer ( $1 \mathrm{mM}$ TRIS- $0.1 \mathrm{mM}$ EDTA, $\mathrm{pH} 8.0$ ) and reprecipitated by added $40 \mu \mathrm{l}$ of $3 \mathrm{M}$ potassium acetate, 2 volumes of cold ethanol and then frozen either for $1 \mathrm{~h}$ at $-70{ }^{\circ} \mathrm{C}$ or overnight at $-20^{\circ} \mathrm{C}$. The nucleic acids were pelleted and dried in a vacuum oven for $30 \mathrm{~min}$, then resuspended in $100 \mu \mathrm{l}$ of TE buffer. The samples were stored at $4{ }^{\circ} \mathrm{C}$ until electrophoresis. The concentration of DNA resulting from this procedure varied from 4 to $5 \mu \mathrm{g}^{-1}$. For electrophoresis of samples, $5 \mu \mathrm{l}$ of DNA was digested with $5 \mu \mathrm{l}$ of restriction endonucleases $E c o$ RI or MspI (Bethesda Research Laboratories, Gaithersburg, MD, USA) following the manufacturer's recommendations. The DNA was then run on a $0.7 \%$ agarose gel in TAE at $30 \mathrm{~V}$ for $16 \mathrm{~h}$. The gel was stained in a solution of $0.5 \mu \mathrm{ml}^{-1}$ ethidium bromide for $30 \mathrm{~min}$ and then destained in water for $60 \mathrm{~min}$ before being photographed.

\section{Reproducibility of sample preparation}

To assess the possibility of artifact induced by sample preparation, $5 \mathrm{C}$. albicans isolates were randomly chosen for serial preparation. Over a 6-week period, each isolate was prepared each week from the original parent stocks stored at room temperature on Sabouraud glucose agar slants. Minor changes in incubation times, enzyme concentrations, and centrifugation times were introduced to replicate "real-life" laboratory procedures in an attempt to test the effect of minor procedural changes on the CHEF banding patterns. The 6 preparations of each isolate were then run side-by-side on the same gel using CHEF electrophoresis.

\section{Reproducibility of CHEF electrophoretic patterns}

We studied the constancy of the electrophoretic banding patterns of $C$. albicans isolates analysed on multiple occasions. Multiple plugs of each of 3 different isolates were prepared on one occasion. Six separate gels were prepared and analysed over 5 weeks. Each isolate was placed in four separate lanes spread equidistant over a 15-lane gel. Each of the six 15-lane CHEF gels thus contained 4 lanes of each of the three isolates (12 lanes) and three lanes for internal standards. Thus, there were a total of 24 analyses per isolate. Data analysis was performed from the photographic enlargements of the stained gels by a single observer.

Two bands were chosen from the internal standard DNA (1600 kb and $945 \mathrm{~kb}$ ) to act as reference points. With the conditions used for electrophoresis, these bands migrated to mid-point and to the far end of the gel, respectively. For each lane on the gel, the distance from the origin to the leading edge of each band was measured in millimeters. In order to compensate for minor run-to-run procedural variations, this distance was compared against one of the reference bands and recorded as a "band migration ratio" (BMR) by the following equation:

$\mathrm{BMR}=\frac{\text { sample band migration }(\mathrm{mm})}{\text { reference band migration }(\mathrm{mm})}$

The total banding pattern for a given isolate was reproduced as a stacked bar graph of its migration ratios. These graphs were then used for direct visual comparison of banding patterns for each isolate.

\section{Constancy of CHEF patterns with morphologic variations}

Three isolates were chosen for analysis. Paired specimens were concurrently passed for 10 generations, either on Sabouraud glucose agar at $30^{\circ} \mathrm{C}$ in room air ("unstressed"), or through 10 generations in 5 different combinations of medium, temperature, and atmosphere ("stressed") as follows: (a) Sabouraud glucose agar, $30^{\circ} \mathrm{C}$, room air; (b) Sabouraud glucose agar, $37^{\circ} \mathrm{C}, 5 \% \mathrm{CO}_{2}$;

mycoses 38, 29-36 (1995) 
(c) trypticase soy agar with $5 \%$ sheep blood (Becton-Dickinson), $37{ }^{\circ} \mathrm{C}, 5 \% \mathrm{CO}_{2}$; (d) trypticase soy agar with $5 \%$ sheep blood, $37^{\circ} \mathrm{C}$, room air, and (e) colistin nalidixic acid agar with $5 \%$ sheep blood (Becton-Dickinson, Cockeysville, MD, USA), $30^{\circ} \mathrm{C}$, room air. Morphologic changes were noted and photographed. Prepared DNA from the parent, "unstressed", and "stressed" isolates were analysed side-by-side on a CHEF gel.

\section{Sensitivity of methods}

Thirty-seven clinical isolates were chosen at random from the larger cohort of isolates. These were analysed by both restriction enzyme analysis and CHEF. The number of unique strains as judged by different patterns of bands was assessed for each of the two electrophoretic techniques.

\section{Results}

\section{Reproducibility of sample preparation}

For each of the 5 clinical isolates tested, CHEF banding patterns from each of 6 separate preparations appeared identical. Thus, sample preparation itself appeared to induce no artifacts (Fig. 1).

\section{Reproducibility of CHEF electrophoretic patterns}

The 3 selected isolates were analysed by CHEF 24 times each -4 lanes on 6 different gels. Gelto-gel variations in the distances migrated by each band in a given isolate occurred, but these were minor (Fig. 2a). These small differences in migration distances were compensated for by the use of the correction factor related to the internal standards, as described in Methods. As shown in the computer representation of the band patterns for all 6 gels, the standard deviation of the migration distance for each band was very small (Fig. 2b).

\section{Constancy of CHEF patterns with morphologic variations}

After 10 generations of passage under varied environmental conditions the 3 different $C$. albicans strains each underwent at least 3 colony morphology changes (Fig. 3). The isolates passaged 10 times in the same environmental conditions, so-called "unstressed" progeny, showed no morphologic changes from the parent strains. CHEF electrophoresis on a single gel with "unstressed", "stressed", and parent isolates showed no changes in CHEF banding patterns between the parent isolate and its progeny (Fig. 4).

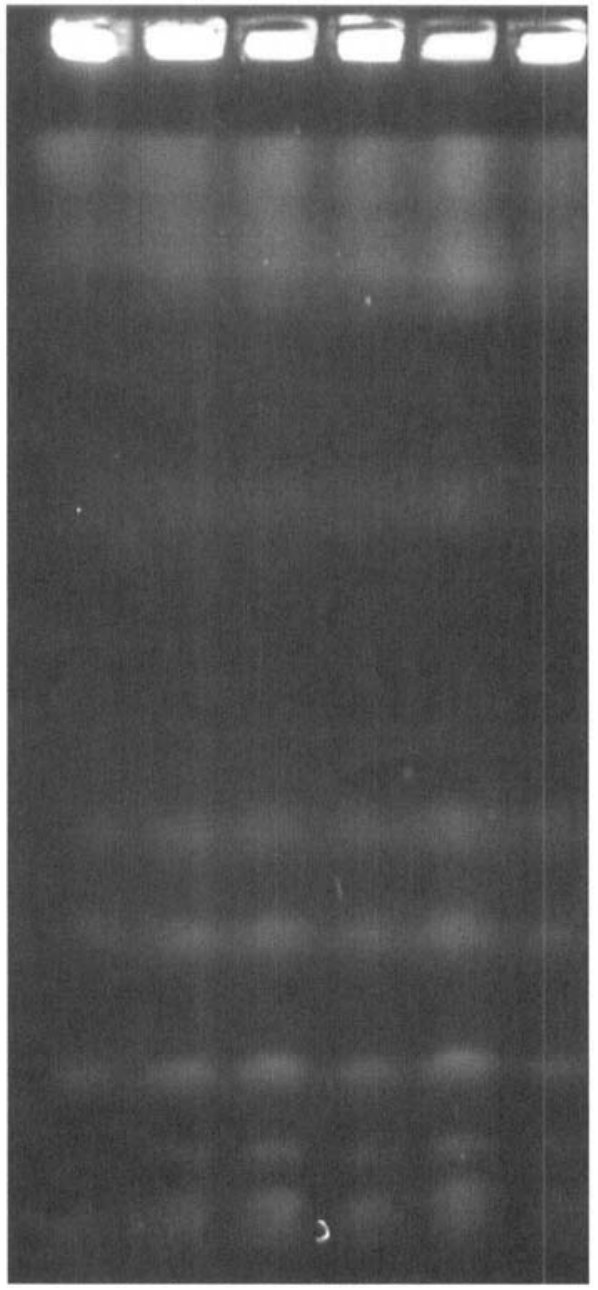

Figure 1. GHEF patterns of a single $C$. albicans isolate. The isolate was prepared on 6 separate occasions, each 1 week apart, and the 6 preparations were then run simultaneously. All lanes show similar banding patterns.

\section{Sensitivity of method}

Analysis of the 37 clinical isolates by restriction enzyme analysis yielded 12 distinct groups (Fig. 5a). CHEF analysis of the same isolates yielded 19 distinct groups (Fig. 5b). Thus, for this small number of isolates, CHEF proved more sensitive at delineating different types than did restriction enzyme analysis.

\section{Discussion}

Although part of the normal microbial flora in humans, many aspects of the epidemiology of C. albicans are unknown. With increased use of immunosuppressive drugs, indwelling central venous access devices, and broad-spectrum antibiotics, and with the advent of the acquired immunodeficiency syndrome, serious Candida infections have increased dramatically [18, 19]. In 1990, 


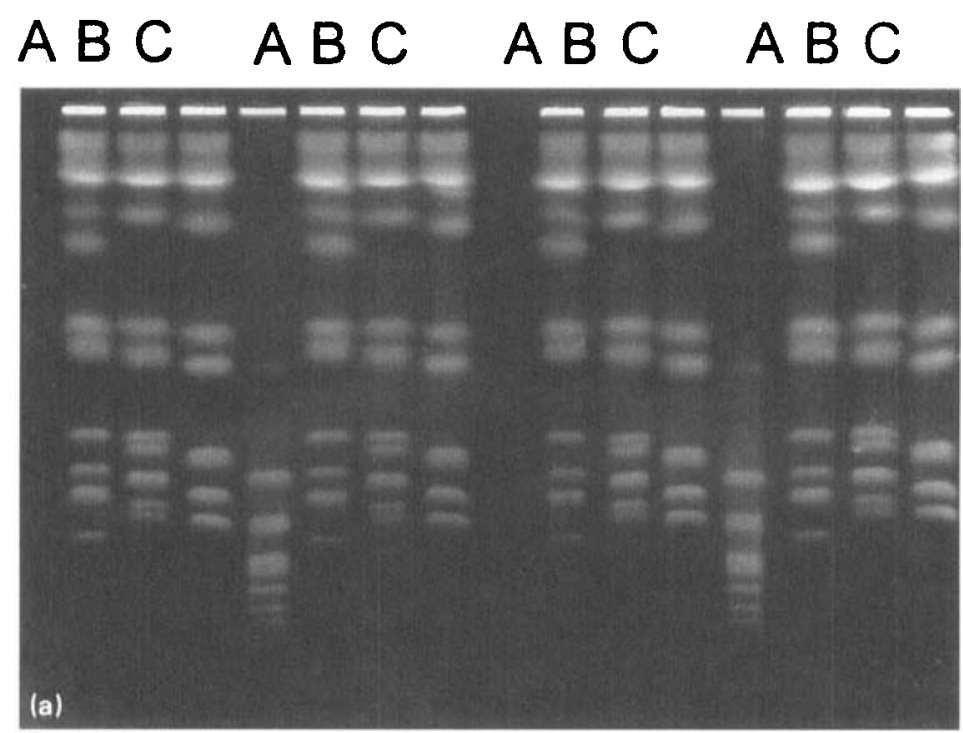

\section{Sample CHEF banding patterns for Candida Albicans}

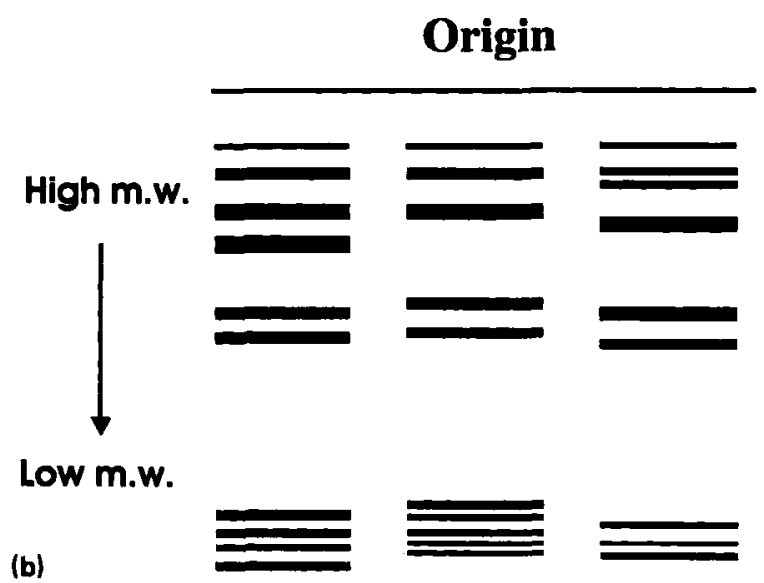

Figure 2. (a) Representative CHEF gel of 3 different $C$. albicans isolates (A, B, C) showing constancy of banding patterns across the gel for each isolate. Lanes 4 and 12 are the $S$. cerevisiae standard. (b) Computer representation of 6 different CHEF gels of the same $3 C$. albicans isolates showing small standard deviations for mean distance each band migrated from baseline (defined by width of each band).

C. albicans was the fourth most common blood culture isolate in the United States, with the greatest increase occurring in large tertiary care centers [20]. Emergence of C. albicans as a major pathogen has sparked renewed interest in the study of its epidemiology.

Epidemiological studies of Candida colonization and infection have lagged because of the lack of a reliable typing system to differentiate strains. Older typing systems have been relatively insensitive and difficult to reproduce [1-6]. Technologic advances have made possible newer typing systems, including DNA probes, restriction enzyme analysis, and CHEF electrophoresis of whole cell intact DNA $[7,9,11]$. Each of these new systems has advantages and disadvantages.

CHEF electrophoresis is simple to perform and requires no toxic chemicals for DNA extraction. The sample preparation is suitable for large batches of isolates, and the prepared specimens may be stored for extended periods before electrophoretic analysis. The procedure does require at least 8 days from initial preparation to final analysis; although lengthy, the actual time spent directly preparing each sample is small.

Although several studies have demonstrated the usefulness of CHEF electrophoresis, some issues regarding its use have not been addressed. Epidemiologic studies which require the comparison of several gels done over time or in different locations will require a typing system which is reproducible in regard to sample preparation, electrophoresis, and data analysis.

The techniques employed in sample preparation

mycoses 38, 29-36 (1995) 


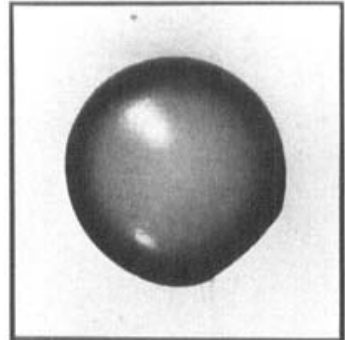

(a)

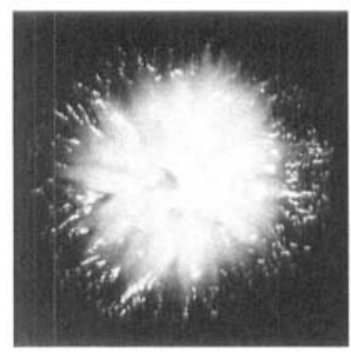

(c)

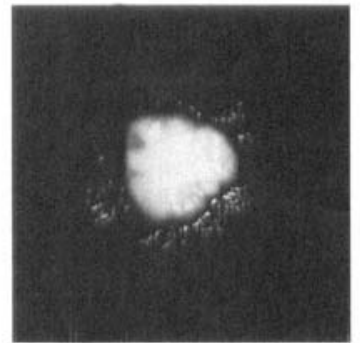

(b)

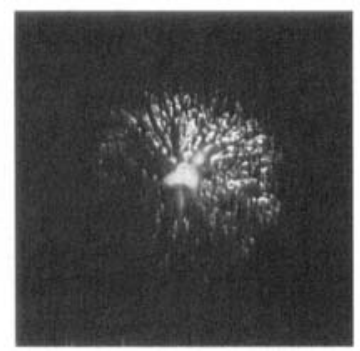

(d)

Figure 3. Morphologic changes induced in one representative C. albicans strain grown under differing environmental conditions. $A=$ Sabouraud glucose agar, $30^{\circ} \mathrm{C}$, room air; $B=$ colistin nalidixic acid agar with $5 \%$ sheep blood, $30^{\circ} \mathrm{C}$, room air; $\mathrm{C}=$ trypticase soy agar with $5 \%$ sheep blood, $37^{\circ} \mathrm{C}$, room air; $\mathrm{D}=$ trypticase soy agar with $5 \%$ sheep blood, $37^{\circ} \mathrm{C}, 5 \% \mathrm{CO}_{2}$.

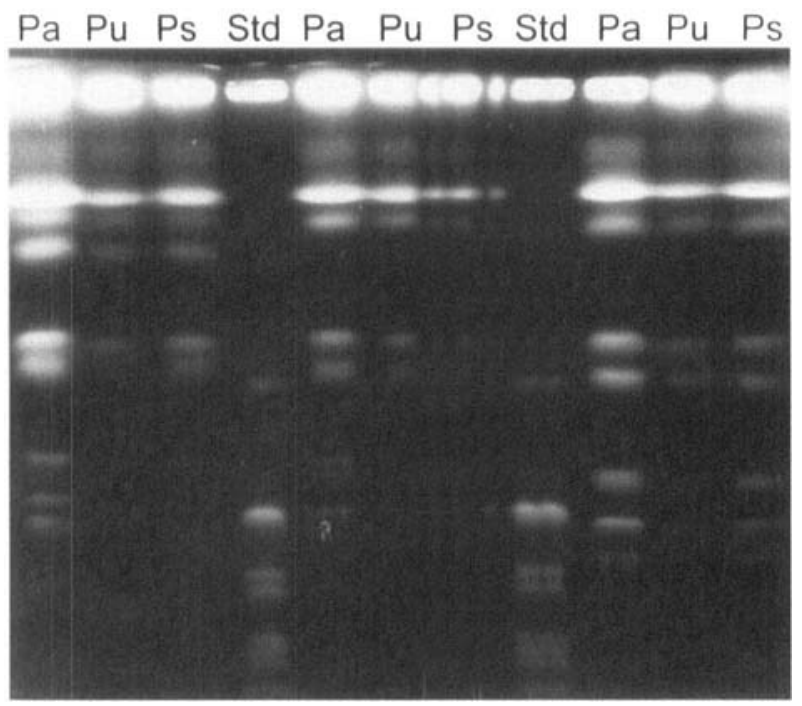

Figure 4. CHEF gel of 3 C. albicans strains showing parent isolate $(\mathrm{Pa})$, progeny which were passaged 10 times under identical conditions (Pu, "unstressed") and showed no morphologic changes, and progeny which were passaged 10 times under varying environmental conditions (Ps, "stressed") and assumed different morphologic configurations. There was no change in the CHEF banding patterns with different colony morphology nor with serial passage under the same environmental conditions. Std $=S$. cerevisiae standard.

are designed to release the cellular DNA as intact chromosomes. Minimal shear forces encountered during preparation can result in chromosomal breakage [21]. As the electrophoretic migration is size-dependent, such breakage would change

banding patterns, making the procedure nonreproducible. In this study we have demonstrated the reproducibility of the method for preparing the DNA. Banding patterns for a given organism were the same in multiple preparations performed at different times.

The electrophoresis procedure and data analysis must allow for minor variations in equipment performance, gel concentration and consistency, and buffer temperature and concentration, which could result in changes in electrophoretic patterns $[22,23]$. Such changes would make longitudinal and geographical comparisons of isolates difficult. We noted variation in band migration between gels. Within a given gel, migration of bands in the outermost lanes was often slower than in the inner lanes. Placement of an internal standard with a known banding pattern in three locations in the gel gave a means for correction of this variability. By comparing specific bands from the standard with the bands from the sample strains, we were able to correct mathematically for variations among gels. Both standard and unknown DNA are subject to and affected by the same local conditions (gel concentration, electric field, temperature). By adjusting sample band migration for migration of the standard bands, reproducibility was enhanced. The result was highly reproducible data analysis without the need for expensive computer equipment.

It has been suggested that $C$. albicans undergoes high frequency chromosomal rearrangement which may, in part, be responsible for morphologic variations $[16,24]$. In this study, morphologic variation was produced, but CHEF banding patterns were not changed. Additionally, patterns remained constant after serial passage through multiple generations. Our environmental "stresses" most likely induced adaptive responses, rather than chromosomal rearrangements. Additional studies would need to be performed to define the effect of mutation on CHEF banding patterns.

In this comparison of a small number of isolates, CHEF electrophoresis was found to be more sensitive than restriction enzyme analysis for differentiation of isolates of $C$. albicans. These results are similar to those noted by Vazquez et al. [11, 17]. However, for other yeasts, such as Candida (Torulopsis) glabrata, restriction enzyme analysis appears to be more sensitive than CHEF [15]. Combining the use of a low frequency cleavage restriction enzyme, such as SmaI or Sfil, with subsequent CHEF electrophoresis appears to be a useful variation which may enhance the delineation of different Candida strains [11, 25]. Further studies comparing CHEF electrophoresis of both uncut DNA and restriction enzyme cut DNA 

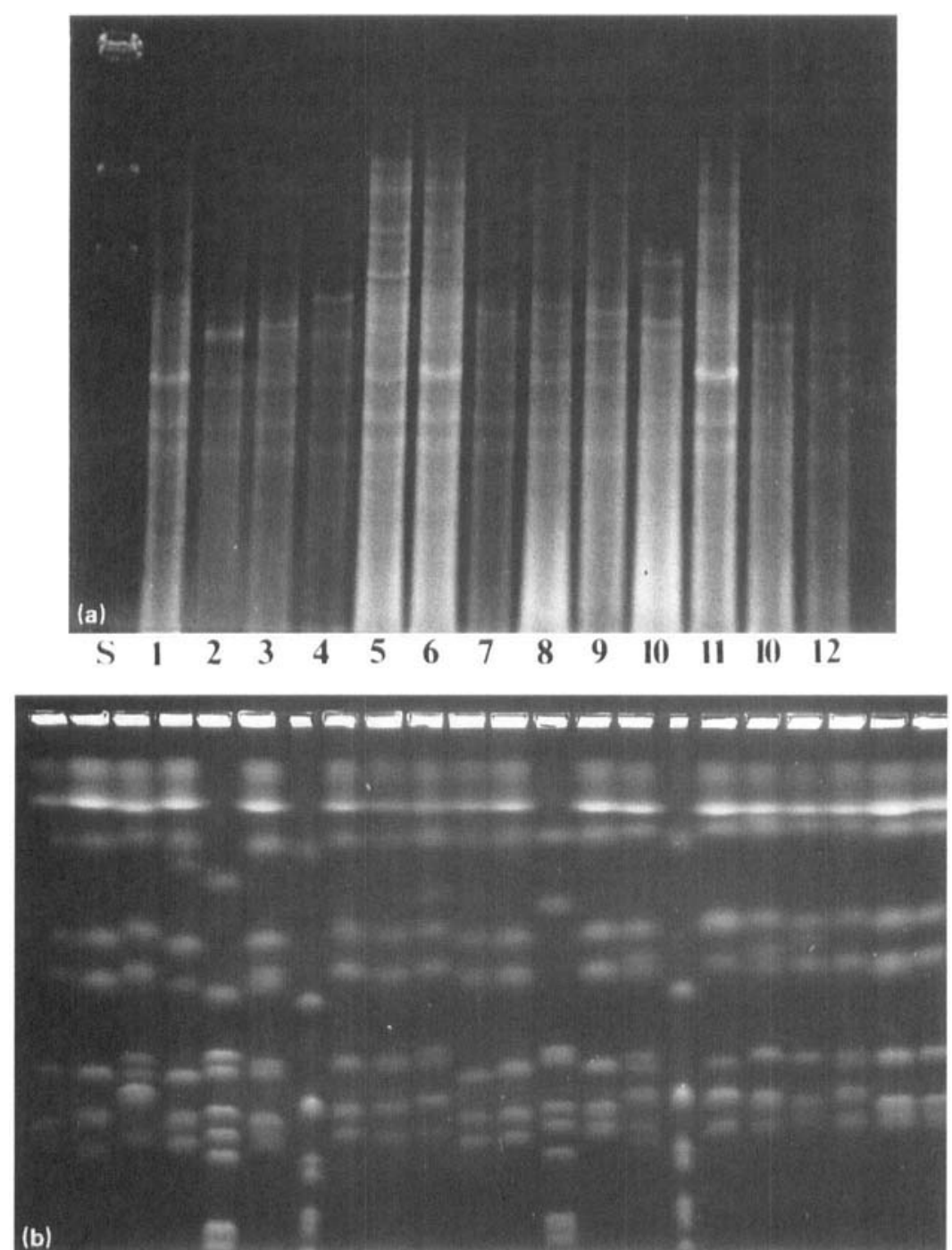

Figure 5. (a) Restriction enzyme analysis using $E c o R I$ endonuclease. Twelve unique patterns were noted among 37 different isolates of C. albicans. All 12 patterns are shown in this composite gel. (b) CHEF electrophoresis showing 11 different strains. Altogether, there were a total of 19 different strains identified among the 37 isolates of C. albicans. Lanes 7 and 16 are the S. cerevisiae standard.

should determine the clinical usefulness of these two techniques.

\section{Acknowledgments}

This study was supported by the Veterans Affairs Health Service Research and Development Service and Pfizer-Roerig, Inc.

\section{References}

1 Odds, F. C. \& Merson-Davies, L. A. (1989) Colony variations in Candida species. Mycoses 32, 275-282.

2 Odds, F. C., Auger, P., Krogh, P., Neely, A. N. \& Segal, E. (1989) Biotyping of Candida albicans: Results of an international collaborative survey. F. Clin. Microbiol. 27, 1506-1509.
3 Brawner, D. L. (1991) Comparison between methods for serotyping of Candida albicans produces discrepancies in results. 7. Clin. Microbiol. 29, 1020-1025.

4 Lehmann, P. F., Kemker, B. J., Hsiao, C.-B. \& Dev, S. (1989) Isoenzyme biotypes of Candida species. 7. Clin. Microbiol. 27, 2514-2521.

5 McCreight, M. C. \& Warnock, D. W. (1982) Enhanced differentiation of isolates of Candida albicans using a modified resistogram method. Mykosen 25, 589-598.

6 Morace, G., Archibusacci, C., Sestito, M. \& Polonelli, L. (1984) Strain differentiation of pathogenic yeasts by the killer system. Mycopathologia 84, 81-85.

7 Merz, W. G. (1990) Candida albicans strain delineation. Clin. Microbiol. Rev, 3, 321-334.

8 Stevens, D. A., Odds, F. C. \& Scherer, S. (1990) Application of DNA typing methods to Candida albicans epidemiology and correlations with phenotype. Rev. Infect. Dis, 12, 258-266.

9 Pfaller, M. A. (1992) Epidemiological typing methods for mycoses. Clin. Infect. Dis. 14, S4-S10.

10 Vazquez, J. A., Sanchez, V., Dmuchowski, C., Dembry, 
L. M., Sobel, J. D. \& Zervos, M. J. (1993) Nosocomial acquisition of Candida albicans: An epidemiologic study. 7. Infect. Dis. 168, 195-201.

11 Dembry, L. M., Vazquez, J. A. \& Zervos, M. J. (1994) DNA analysis in the study of the epidemiology of nosocomial candidiasis. Infect. Control Hosp. Epidemiol. 15, 48-53.

12 Schwartz, D. C. \& Cantor, C. R. (1984) Separation of yeast chromosome-sized DNAs by pulsed field gradient gel electrophoresis. Cell 37, 67-75.

13 Pittet, D., Monod, M., Filthuth, I., Frenk, E., Suter, P. M. \& Auckenthaler, R. (1991) Contour-clamped homogeneous electric field gel electrophoresis as a powerful epidemiologic tool in yeast infections. Am. 7. Med. 91, 256S-263S.

14 Doebbeling, B. N., Lehmann, P. F., Hollis, R. J. et al. (1993) Comparison of pulsed-field gel electrophoresis with isoenzyme profiles as a typing system for Candida tropicalis. Clin. Infect. Dis. 16, 377-383.

15 Vazquez, J. A., Beckley, A., Donabedian, S., Sobel, J. D. \& Zervos, M. J. (1993) Comparison of restriction enzyme analysis versus pulsed-field gradient gel electrophoresis as a typing system for Torulopsis glabrata and Candida species other than C. albicans. F. Clin. Microbiol. 31, 2021-2030.

16 Soll, D. R. (1992) High-frequency switching in Candida albicans. Clin. Microbiol. Rev. 5, 183-203.

17 Vazquez, J. A., Beckley, A., Sobel, J. D. \& Zervos, M. J. (1991) Comparison of restriction enzyme analysis and pulsed-field gradient gel electrophoresis as typing systems for Candida albicans. 7. Clin. Microbiol. 29, 962-967.

18 Klein, R. S., Harris, C. A., Small, C. B., Moll, B., Lesser, M. \& Friedland, G. H. (1984) Oral candidiasis in high-risk patients as the initial manifestation of the acquired immunodeficiency syndrome. $\mathcal{N}$. Engl. J. Med. 31, 354-358.
19 Komshian, S. V., Uwaydah, A. K., Sobel, J. D. \& Crane, L. R. (1989) Fungemia caused by Candida species and Torulopsis glabrata in the hospitalized patient: Frequency, characteristics, and evaluation of factors influencing outcome. Rev. Infect. Dis. 11, 379-390.

20 Banerjee, S. N., Emori, T. G. \& Culver, D. H. (1991) Secular trends in nosocomial primary bloodstream infections in the United States. 1980-1989. Am. J. Med. 91(3B), 865-895.

21 Lai, E., Birren, B. W., Clark, S. M., Simon, M. I. \& Hood, L. (1989) Pulsed field gel electrophoresis. Bio Techniques 7, 34-42.

22 Mathew, M. K., Smith, C. L. \& Cantor, C. R. (1988) High-resolution separation and accurate size determination in pulsed-field gel electrophoresis of DNA. 1. DNA size standards and the effect of agarose and temperature. Biochemistry 27, 9204-9210.

23 Mathew, M. K., Smith, C. L. \& Cantor, C. R. (1988) High-resolution separation and accurate size determination in pulsed-field gel electrophoresis of DNA. 2. Effect of pulse time and electric field strength and implications for models of the separation process. Biochemistry 27, 9210-9216.

24 Morrow, B., Srikantha, T., Anderson, J. \& Soll, D. R. (1993) Coordinate regulation of two opaque-phase-specific genes during white-opaque switching in Candida albicans. Infect. Immun. 61, 1823-1828.

25 Voss, A., Pfaller, M. A., Hollis, R. J., Rhine-Chalberg, J. \& Doebbeling, B. N. (1995) Investigation of $C$. albicans transmission in a surgical intensive care unit cluster with genomic DNA typing methods. F. Clin. Microbiol. 33, $576-580$. 